I Wayan Ardika (2009): Blanjong: An Ancient Port Site in Southern Bali, Indonesia. In: Elfriede Hermann, Karin Klenke und Michael Dickhardt (Hg.): Form, Macht, Differenz. Motive und Felder ethnologischen Forschens. Göttingen: Universitätsverlag Göttingen, 251-258. Doi: $10.17875 /$ gup 2020-1289

\title{
Blanjong: An Ancient Port Site in Southern Bali, Indonesia
}

\author{
I Wayan Ardika
}

The archeology of Bali is not only a vast and interesting field, but also an area of recent fruitful interdisciplinary research between Brigitta Hauser-Schäublin and myself, which resulted in the book "Burials, Texts and Rituals. Ethnoarcheaological Investigations in Northern Bali, Indonesia" (Hauser-Schäublin and Ardika 2008). Our studies focused on the villages of Sembiran and Julah in northern Bali, which were harbour and trading centers for over 1000 years in transmarine trade between India and China. In this contribution I will concentrate on Blanjong, an archaeological port site in southern Bali, and its economic and political importance.

\section{Inscriptional Evidence for Dating the Site}

Blanjong is located in the tourist area of Sanur in southern Bali. Upon the discovery of a stone inscription at Blanjong, the area has attracted the attention of historians, and especially epigraphists from the 1930s onwards. The inscription is written in two types of scripts (biscript) and two languages (bilingual). One side (side A) of the inscription was written in the Nagari script with Old Balinese language and the other side (side B) was written in Kawi style script with Sanskrit language.

According to Stutterheim (1934), the appearance of a Nagari script and the Sanskrit language in the inscription of Blanjong suggests that North Indian cultures had 
already been influencing Bali in the $10^{\text {th }}$ century $\mathrm{AD}$. He assumes that Blanjong could be an ancient port site where Indian traders might have been active as early as the $10^{\text {th }}$ century AD. A chronogram which was depicted on the Blanjong inscription was read by Sten Konow as "khecara wahnimurti ganite" which is equal to the year 839 (year AD 764) in the Balinese Saka calendar (cit. in Stutterheim 1934:128). Based on the similarities between the inscription of Blanjong and contemporary Indian inscriptions, Casparis (1975:37) believes that there was direct Indian influence on Bali.

Damais (1951) made a correction of Konow's interpretation of the chronogram of the Blanjong inscription, as he read the chronogram as saka'bde sara wahnimurti ganite which is equal to the Saka year 835 or AD 913. As of yet, the problem of the correct translation of the date has not been solved.

\section{Material Evidence for Dating the Site}

Based on the discovery of the Blanjong inscription and some fragments of a monument and statues found at the site, Ardika (1981:20) conducted a systematic archaeological survey at Blanjong in 1980. This survey produced significant archaeological data including potsherds and ceramics which tend to concentrate around $300 \mathrm{~m}$ southwest and northeast of the Blanjong inscription. Over the last three years, the Department of Archaeology, Faculty of Letters, of Udayana University in collaboration with the National Archaeological Research Center in Jakarta has conducted excavations at Blanjong. These programmes excavated nine trenches (Blanjong I-IX) and produced potsherds, Chinese ceramics and animal bones as well as human burial remains (Tim Jurusan Arkeologi 2006, 2007, 2008). The Chinese ceramics have been identified to include Tang, Sung and Yuan specimens dated from $7^{\text {th }}-10^{\text {th }}$ century AD (John Miksic, personal communication 2007; Tim Jurusan Arkeologi 2006, 2007, 2008). ${ }^{1}$

The inscriptional data, the discoveries of Chinese ceramics and the geographical setting of the site itself indicate that Blanjong could be a port site in southern Bali dating back to at least the early $10^{\text {th }}$ century $\mathrm{AD}$ or that it is contemporary with the Blanjong inscription (AD 913). Bali's northeastern coast has at least one ancient port site - the already mentioned Julah including Pacung and Sembiran - which has been identified (Ardika 1991, 2008). This assumption is also based on inscriptional data of Julah and Sembiran and on the archaeological data, in particular some Indian potteries found at the site.

\section{The Political Importance of Blanjong}

The inscription of Blanjong mentions that Adhipatih (King) Kesari defeated his enemies at Gurun and Suwal in Saka 835 or AD 913 (Goris 1954:64-65)2. Similar inscrip- 
tions have also been discovered at the villages of Malat Gede and Panempahan around Tampaksiring in central Bali. The inscriptions of Malat Gede were edited in the Saka year of 835 during the month of Phalguna. The date of the inscription of Panempahan is illegible, thus the time of editing is unclear, yet the month Phalguna remains the same. These three inscriptions mention that King Kesari defeated his enemies probably around Tampaksiring in central Bali and around Blanjong in the coastal area of southeastern Bali. Sukarto (1967) believes that King Kesari could be the founding father of the Warmmadewa dynasty in Bali, since he was the first name of a king mentioned in the Balinese inscriptions.

The inscriptional data thus suggests that the site of Blanjong could be an important place for King Kesari Warmmadewa in defeating his enemies at Gurun and Suwal. The inscription of Blanjong itself was made of stone or tuff, which is not available around the coastal area of Blanjong/Sanur. This indicates that it must have been brought from another area or an inland site. Like the Malat Gede and Panempahan inscriptions, the Blanjong one was also a jaya stambha or a symbol of victory for Kesari Warmmadewa in defeating his enemies.

This paper will further discuss the role of King Kesari Warmmadewa, who was the first Balinese king mentioned in Balinese inscriptions and the founding father of the Warmmadewa dynasty which reigned Bali between the $9^{\text {th }}$ and the $14^{\text {th }}$ centuries AD.

\section{King Kesari Warmmadewa}

Prior to the inscriptions referring to King Kesari Warmmadewa at Blanjong, Malat Gede and Panempahan, seven other inscriptions had already been found in Bali. These inscriptions, which do not mention names of kings, include Sukawana AI (Saka 804 or 882 AD), Bebetin AI (Saka 818 or 896 AD), Trunyan AI (Saka 813 or 891 AD), Trunyan B (Saka 833 or 911 AD), Bangli Pura Kehen A (the date is illegible), Gobleg Pura Desa I (Saka 836 or 914 AD) and Angsari A (without dating) (Goris 1954:53-62). Most of these inscriptions were published or edited at the place called Panglapuan at Singhamandawa.

Side A of the Blanjong inscription in a Nagari script using the Old Balinese language mentions the chronogram cake bde cara wabnimurtiganite (Saka 835) in the month of Phalguna (the eight month of the Saka year) and the place's name, Singhadwala. The name of the king who defeated his enemies at Gurun and Suwal is Sri Kesari (Goris 1954:64-65). On side B of the Blanjong inscription, which was written in Kawi script using the Sanskrit language, the word walidwipa (probably meaning "the island of Bali") and "Adhipatih Sri Kesari Warmmadewa" is mentioned (Goris 1954:65; Bernet Kempers 1991:35-38, fig.24). Since most of the texts of the Blanjong inscription are illegible, our knowledge of the historical events which occurred in Saka 835 or 913 $\mathrm{AD}$ is still limited. On the basis of the Blanjong inscription, however, we can assume 
that Adhipatih (King) Sri Kesari Warmmadewa erected a stone or tuff pillar at Blanjong to commemorate his victory against his enemies at Gurun and Suwal in Saka 835 or $913 \mathrm{AD}$. We could also identify the name of places called Singhadwala (probably the palace of King Kesari) and Walidwipa (probably the island of Bali).

Many scholars have put forth differing arguments concerning the place of Gurun and Suwal. Stutterheim (1934:130) argued that Gurun might be Nusa Penida, a small island east of Bali. Goris however believed that Gurun was Lombok, and interpreted Suwal as Ketewel beach south of Sukawati in the Gianyar regency. Wherever Gurun and Suwal might have been located historically, Blanjong-Sanur seems to have been an important site in relation to the Kesari expansion.

It should be noted that the inscriptions of Blanjong, Malat Gede and Panempahan all commemorate the victories of King Kesari Warmmadewa against his enemies. Unlike the Blanjong inscription, neither the Malat Gede nor the Panempahan inscription indicates who Kesari's enemies were. However, the most important observation is that King Kesari Warmmadewa claimed to have defeated his enemies both inland and at coastal areas and possibly outside of Bali as well. He commemorated his victory by establishing these three stone pillars at Blanjong, Malat Gede and Panempahan between the $29^{\text {th }}$ of January and the beginning of February, $914 \mathrm{AD}$. These events might have also reinforced his legitimacy as the founder of the Warmmadewa dynasty in Bali, for his successors also bore the title Warmmadewa after their name, as for instance Tabanendra Warmmadewa (955-967 AD), Jayasingha Warmmadewa (960 AD), Sri Janasadhu Warmmadewa (975 AD), and Udayana Warmmadewa (993-1011 AD) (Goris 1954:74-94; Ardika 1987:53). It should be noted, however, that Sang Ratu Ugrasena, who reigned from 915 to $936 \mathrm{AD}$, never used the title Warmmadewa, unlike his predecessor and his successor did. The question of whether Ugrasena was a true member of the Warmmadewa dynasty remains to be answered.

\section{Early State Formation}

Based on the inscriptions at Blanjong, Malat Gede and Panempahan, it seems that conflict or warfare occurred in Bali between King Kesari Warmmadewa and his enemies. Conflicts also occurred during the emergence of early states in other regions such as the empire of Sriwijaya (South Sumatra), Taruma Negara (West Java), and Mataram (Central Java).

\section{The Kingdom of Sriwijaya}

For instance, the Kedukan Bukit inscription which can be found near Palembang (Sumatra) and dates back to April 23rd, $682 \mathrm{AD}$, indicates that Dapunta Hyang carried out an expedition to Matayap, departing from Minanga Tamwan. This expedition consisted of two hundred sailors and two thousand troops. Dapunta Hyang arrived 
at Matayap, claimed victory and then built Sriwijaya after conquering other regions (Coedes 1968:82; Hall 1985:78-83).

Three other inscriptions which suggest similar situations, include those of Kota Kapur (Bangka) from 686 AD, Karang Birahi in Jambi Hulu, 686 AD, and Palas Pasemah in Southern Lampung, also from around the end of the $7^{\text {th }}$ century AD (Bambang Sumadio 1977:54). Based on these inscriptions, it seems that Dapunta Hyang defeated his rivals around Jambi (Melayu), Palembang and South Lampung in Sumatra and on Bangka island in order to establish his legitimacy and hegemony as the ruler of the empire of Srivijaya.

\section{The Kingdom of Taruma}

Purnawarman's inscriptions in West Java tell us implicitly the same story. These include the inscriptions of Ciaruten, Pasir Koleangkak and Kebon Kopi. None of these are dated, but on the basis of paleography it has been argued that they derive from the $5^{\text {th }}$ century AD (Coedes 1968:53). Adjacent to these inscriptions footprints were also found. The inscription of Ciaruten consists of four lines. It mentions that the footprints engraved on it belong to Purnawarman, the strong and brave king of Taruma. These footprints were associated with the footprints of Wisnu as a symbol of victory (Coedes 1968:53-54; Sumadio 1977:38-39; Hall 1985:105). The Pasir Kolaengkak inscription also states that its footprints are from Purnawarman, the king of Taruma, who always defeated his enemies. The inscription of Kebon Kopi records that the footprints on the inscription were those of the elephant of the king of Taruma, a connection similar to that between the elephant of Airawata and Indra as God of war.

\section{The Kingdom of Mataram}

The records concerning the emergence of the early state of Mataram in Central Java offer a similar picture. The inscription of Canggal dated to $732 \mathrm{AD}$ was written in the Palawa script using the Sanskrit language. It commemorated the erection of a lingga at a place called Kunjarakunja on the island of Java which was rich in rice and gold mines. The inscription states that the island of Java (Jawadwipa) was governed formerly by King Sanna. When he died, the kingdom suffered as the people had lost their protector. Sanna was succeeded by his nephew Sanjaya, a strong and brave king who conquered other regions and created prosperity for his people. It is interesting to note that a late text called Ceritra Parahyangan recorded that Sanjaya conquered many regions including Cambodia, Melayu (Sumatra), West Java, East Java, and Bali (Coedes 1968:87-89; Hall 1985:119). However, the significance of the Cerita Parahyangan in relation to the emergence of the early state in Bali in the $9^{\text {th }}$ century $\mathrm{AD}$ is still unclear. 


\section{Conflicts and Status Rivalry}

Warfare and conflicts during the formation of states were, as we have seen, common in the archipelago now known as Indonesia and were often motivated by economic interests. As noted above, conflicts or warfare also occurred in Bali during the reign of King Kesari Warmmadewa, and possibly also prior to that period. However, the warfare during King Kesari Warmmadewa's reign can best be understood as indicative of political pressure in terms of status rivalry rather than of economic pressure. King Kesari, who adopted aspects of Indian culture, had defeated his rivals in order to establish himself as the founder of the Warmmadewa dynasty in Bali. As mentioned in the inscription of Panempahan, after King Kesari defeated his enemies, he unified the island under his sovereignty (Sukarto 1976:156). In this case, warfare can be seen simply as a result rather than a cause of state formation in Bali. After he unified the island of Bali, Kesari Warmmadewa claimed himself as the founder of Warmmadewa dynasty in Bali. This dynasty reigned in Bali from the early $10^{\text {th }}$ up to the mid $14^{\text {th }}$ century $\mathrm{AD}$. But warfare by itself cannot create states. The control and the coordination of warfare and defense and the capacity to settle disputes are the more essential core features. War helps to make states, states make war, and therefore states are in part, and must always be, war machines.

\section{Conclusion}

Based on inscriptional data and archaeological remains, Blanjong probably can be understood as an important port site in the southern part of Bali at least in the early tenth century $\mathrm{AD}$. The Blanjong inscription is the only stone inscription so far found in southern Bali which commemorated the victory of Kesari Warmmadewa. It was also a place of significance for Kesari Warmmadewa who defeated his enemies in the southern coastal area of Bali and possibly outside of Bali. The interpretation of inscriptions and material remains clearly points "outwards" to the involvement of Balinese port sites in transmarine trade with its implication of cultural exchange, but also "inwards" to processes of state formation and conflicts over succession.

\section{Notes}

1 Pandit Shastri already suggests in his book "Sedjarah Bali Dwipa" (1963) that Blanjong could be an ancient port site and one of the gateways to Bali. He also mentioned that Tang ceramics had been found around the Blanjong site.

2 Transcriptions of the Blanjong inscription have been presented by Goris (1954:64-65), who is one of the best known Balinese epigraphists.

3 A lingga is a stone in the shape of a phallus. 


\section{References}

Ardika, I Wayan (1981) Desa Sanur ditinjau dari Arkeologi. Laporan Penelitian. Denpasar: Universitas Udayana.

Ardika, I Wayan (1987) Bronze Artifacts and the Rise of Complex Society in Bali. Unpublished Thesis. Canberra: Australian National University.

Ardika, I Wayan (1991) Archaeological Research in Northeastern Bali, Indonesia. Dissertation. Canberra: Australian National University.

Ardika, I Wayan (2008) Archaeological Traces of the Early Harbour Town. In: Brigitta Hauser-Schäublin and I Wayan Ardika (eds): Burials, Texts and Rituals. Ethnoarchaeological Investigations in North Bali, Indonesia. Göttingen: Universitätsverlag Göttingen.

Bernet Kempers, August Johan (1991) Monumental Bali. Introduction to Balinese Archaeology \& Guide to the Monuments. Berkeley: Periplus Edition.

Casparis, J.G. de (1975) Indonesian Palaeography. A History of Writing in Indonesia from the Beginning to C.A.D. 1500. Leiden and Köln: Brill.

Coedes, George (1968) The Indianized States of Southeast Asia. Honolulu: East-West Centre Press.

Damais, Louis-Charles (1951). Études Balinaises. La Colonnette de Sanur. Le Bulletin de l'École Française d'Extrême-Orient 44(1):121-140.

Goris, Roelof (1954) Prasasti Bali 1-2. Bandung: Masa Baru.

Hall, Kenneth R. (1985) A History of Southeast Asia. London: Macmillan St. Martin's Press.

Hauser-Schäublin, Brigitta and I Wayan Ardika (eds) (2008) Burials, Texts and Rituals. Ethnoarchaeological Investigations in North Bali, Indonesia. Göttingen: Universitätsverlag Göttingen.

Pandit Shastri, Narendra Dev (1963) Sedjarah Bali Dwipa. Denpasar: Bhuvana Saraswati.

Sukarto, K. Atmodjo. (1967) Penyelidikan Empat Buah Prasasti Baru di Bali. Denpasar: Fakultas Sastra Universitas Udayana.

Sukarto, K. Atmodjo (1976) A Newly Discovered Pillar Inscription of Sri Kesariwarma (dewa) at Malat Gede.

Stutterheim, Willem F. (1934) A Newly Discovered Pre-Nagari Inscription on Bali. Acta Orientalia 12:126-132. 
Sumadio, Bambang (ed.) (1977) Sejarah Nasional II. Zaman Kuno. Jakarta: Balai Pustaka.

Tim Jurusan Arkeologi (2006) Pelatihan Ekskavasi Arkeologi di Situs BlanjongSanur,Denpasar, Bali. Laporan Penelitian. Denpasar: Fakultas Sastra Universitas Udayana.

Tim Jurusan Arkeologi (2007) Training (Praktikum) Ekskavasi Arkeologi di Situs Blanjong-Sanur, Denpasar, Bali. Laporan Penelitia. Denpasar: Fakultas Sastra Universitas Udayana.

Tim Jurusan Arkeologi (2008) Training (Praktikum) Ekskavasi Arkeologi di Situs Blanjong-Sanur, Denpasar, Bali. Laporan Penelitian. Denpasar: Fakultas Sastra Universitas Udayana. 